\title{
Reduction of COD and BOD concentration in lake water of universitas indonesia with microbial desalination cell system and utilizing bio charcoal as electrode
}

\author{
Hidayati Istiqomah ${ }^{1}$, Putri Anggun Puspitarini ${ }^{1}$, Putty Ekadewi ${ }^{1}$, Tania Surya Utami $^{*}{ }^{*}$, Rita Arbianti ${ }^{1}$, Heri Hermansyah $^{1}$ \\ ${ }^{1}$ Department of Chemical Engineering, Faculty of Engineering Universitas Indonesia, Depok 16424, Indonesia
}

\begin{abstract}
One of the most promising areas with the existence of the lake is Universitas Indonesia. Universitas Indonesia (UI) has six lakes with a total area of $269,107 \mathrm{~m}^{2}$ which is very important for its existence to balance the surrounding environment. Currently, the existence of UI lake has been contaminated with the COD value of about 1 to $8.000 \mathrm{mg} / \mathrm{L}$ due to a lot of garbage that enters and buried in it, that more attention is needed so that pollution will not increase. Microbial Desalination Cell (MDC) is a development system of Microbial Fuel Cell (MFC), which has the ability to desalinate seawater and can produce electricity by using microorganisms as waste decomposers. In addition, MDC method can also reduce the level of waste contained in the substrate used. To improve the performance of MDC, this study utilizes bio charcoal from rice husks to assess the performance of sodium percarbonate in the cathode chamber with a variation of $0.05 \mathrm{M}$ concentration; $0.1 \mathrm{M} ; 0.15 \mathrm{M}$; and $0.2 \mathrm{M}$, and the performance of the addition of bacteria consortium on the substrate. The best results of this MDC study, in the variation of 0.15 $M$ sodium percarbonate concentration with a decrease of COD and BOD of $93.98 \%$ and $87.67 \%$ and in variation of addition of bacteria consortium of $1 \mathrm{~mL}$ with decrease of COD and BOD $90.04 \%$ and $50.52 \%$.
\end{abstract}

\section{Introduction}

One of the most promising areas with the existence of the lake is Universitas Indonesia. Universitas Indonesia (UI) has six lakes with a total area of $269,107 \mathrm{~m}^{2}$ which is very important for its existence to balance the surrounding environment. The six lakes are Kenanga lake, Agathis lake, Mahoni lake, Puspa lake, Ulin lake, and Salam Lake ${ }^{[1]}$. UI Lake can make the air within the campus relatively damp and cause a sense of cool ${ }^{[2]}$. With a catchment area of 800-1000 hectares, UI lake holds water in order not to overflow to Jakarta by sinking it into the ground into a groundwater reserve ${ }^{[2]}$. Currently the existence of Lake UI has been contaminated because a lot of garbage that enters and buried in it. There are at least three sources of UI lake contamination, that is from the Depok market, Kampung Bambon, and Beji Kukusan ${ }^{[2]}$. Annual data snippet from the Department of Chemistry FMIPA UI which notes the high levels of $\mathrm{KMnO}_{4}$. These compounds are harmful to water and the environment as they can be very toxic to aquatic creatures with long term impact ${ }^{[3]}$. In addition there is also oil content in water that can threaten the survival of fish in the lake ${ }^{[3]}$. It is concluded that the existence of the lake at the Universitas Indonesia as one of the supporters of environmental balance should get more attention, because if the pollution is getting worse will cause damage to ecosystem for the living creatures around it.
Overcoming the problems that occur in the lake UI to remain one of the areas supporting the balance of the environment in Depok City, one of the methods used is MDC (Microbial Desalination Cell). The MDC method can also be used for wastewater treatment based on the simplest MDC reactor design, so the MDC method can reduce the concentration of waste contained in the substrate. The simplest MDC reactor design comprises three chambers separated by an Anion Exchange Membrane (AEM) on the chamber anode and Cation Exchange membrane (CEM) on the cathode chamber, as well as the center chamber for saline solution between the two membranes ${ }^{[4]}$. In this research, UI lake water is used as organic material or substrate, where the largest lake in UI is selected, that is Ulin lake with an area of $55,341 \mathrm{~m}^{2}$. In the cathode chamber the material selected as catholyte is sodium percarbonate $\left(2 \mathrm{NaCO} \cdot 3 \mathrm{H}_{2} \mathrm{O}_{2}\right)$.

This MDC research focusing on wastewater treatment is expected to reduce the levels of Chemical Oxygen Demand (COD) and Biochemical Oxygen Demand (BOD) in the lake water waste UI optimally, so it can be used on a large scale and a solution to the problems of lake conditions in the Universitas Indonesia and in Indonesia. The purposes of this research are studying the effect of sodium percarbonate concentration on the MDC system and studying the optimum concentration of sodium percarbonate to reduce the levels of COD and BOD in UI lake water and studying the effect of addition of bacteria consortium on

\footnotetext{
Corresponding author: nana@,che.ui.ac.id
} 
decreasing levels of COD and BOD in UI lake water in the MDC system.

\section{Methodology Experimental}

\subsection{MDC reactor preparation}

MDC reactors used in this study have three chambers, it is anode chamber, salt chamber and cathode chamber. The anode, salt, and cathode chambers are arranged by inserting AEM between the anode and salt chamber, as well as the CEM between the desalination chamber and the cathode chamber, as well as the electrodes, power lines, and resistor. Comparison between anode chamber : salt : cathode designed to approach 4: $1: 2^{[5]}$. In the reactor circuit there is also an anode and cathode electrode connected to a $10 \mathrm{ohm}$ resistor (inhibitory medium $)^{[6]}$. After the reactor is finished, conduct a leak test before the experiment.

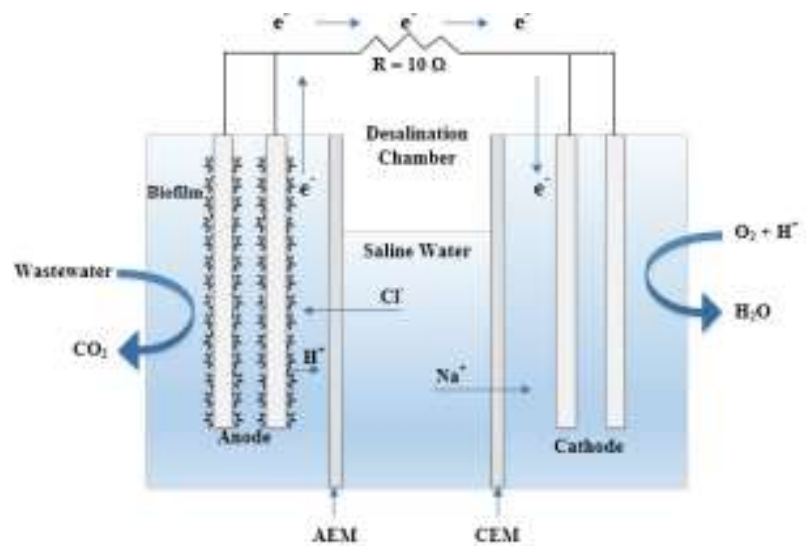

Fig 1. Scheme of MDC reactor

Source : Azizah, 2017

In the anode chamber, used Ulin lake water as anolyte (substrats) without treatment and inoculated immediately after taking. Cathode chamber used sodium percarbonate with variant concentrations of $0.05 \mathrm{M}, 0.1$ $\mathrm{M}, 0.15 \mathrm{M}$, and $0.2 \mathrm{M}$ as catholyte. In the salt chamber used seawater model it is a $\mathrm{NaCl}$ solution of $30 \mathrm{~g} / \mathrm{L}$. MDC was operated in a batch system at room temperature and one cycle lasts for 50 hours of operating time.

\subsection{Preparation of rice husk charcoal bioeletrode}

The coating process is a necessary process to maintain the shape of the bio charcoal. Type of stainless steel used is SS 304 with a mesh shape that serves as a collector of electric current. Stainless steel used is $12.5 \mathrm{~cm} \mathrm{x} 9.5 \mathrm{~cm}$. Prior to the coating process, stainless steel was immersed at room temperature within $\mathrm{H}_{2} \mathrm{SO}_{4}$ for $24 \mathrm{~h}$ to remove surface oxide in steinless steel ${ }^{[4]}$.

The method of stainless steel mesh coating with natural charcoal is as follows, first making a PVA solution with a composition of $3 \mathrm{gr}$ of PVA, $30 \mathrm{~mL}$ of water and $24 \mathrm{~mL}$ of ethanol by heating at a temperature of $120^{\circ} \mathrm{C}$ and continuously stirring; mix $12 \mathrm{gr}$ of saturated charcoal into $18 \mathrm{~mL}$ of Poly Vinyl Alcohol (PVA) solution; coat each stainless steel mesh with charcoal paste by means of horizontally applied. To remove metal contaminants and inorganic compounds, bioelectrode were immersed in $0.1 \mathrm{M} \mathrm{HCl}$ solution for 24 hours, then were rinsed with distilled water, followed by immersion in $0.1 \mathrm{M} \mathrm{NaOH}$ solution for 24 hours then rinsed again with distilled water and remain stored in distilled water until use.

\subsection{Data Analysis}

To analysis data in this experiment, levels of COD and BOD were measured in the wastewater before and after the experiment conducted. Measurement COD levels used by spectrophotometri method with reagents used were HACH COD reagents Cat. 2125925 20-1500 mg/L. Measurement BOD levels was conducted using BOD $_{5(20)}$ methods and the solubility of oxygen was measured using Dissolved Oxygen (DO) meter Hanna HI 7041s instrument. The electrolyte $\mathrm{pH}$ was measured in the before and after of the experiment using $\mathrm{pH}$ meter (EUTECH Instrument Model EcoTestr pH 2).

\section{Result and Discussions}

\subsection{Experiment with Sodium Percarbonate Variation}

In this experiment the MDC system uses sodium percarbonate variation as a catholyte. Based on experiments Putri (2017), anode made from rice husk charcoal is the best anode to reduce the levels of COD and BOD on the substrate used ${ }^{[7]}$. The purpose of this research is to know the effect of sodium percarbonate concentration on the decrease of COD and BOD water level of UI lake in MDC system, and to know the optimum concentration. The variation of the concentration of sodium percarbonate used was $0.05 \mathrm{M}$; $0.1 \mathrm{M} ; 0.15 \mathrm{M}$; and $0.2 \mathrm{M}$. UI lake water and sodium percarbonate are used without any treatment or addition and the MDC system operates for 50 hours in a batch reactor.

The decreasing performance of COD and BOD levels on the variation of sodium percarbonate concentration can be seen in Fig. 2 and Fig. 3. Fig. 2 shows that the highest decrease of COD concentration is at $0.15 \mathrm{M}$ sodium percarbonate concentration, ie from $1089.5 \mathrm{mg} / \mathrm{L}$ to $65.5 \mathrm{mg} / \mathrm{L}$ with COD decrease $93.98 \%$, followed by concentration of sodium percarbonate $0.1 \mathrm{M}$ (COD removal $=91.88 \%$ ), then $0.2 \mathrm{M}$ sodium percarbonate concentration $(\mathrm{COD}$ removal $=75.93 \%)$, and lowest at $0.05 \mathrm{M}$ sodium percarbonate concentration (COD removal $=71.12 \%$ ). The decrease in BOD can be seen in Fig. 3, where the result is slightly different with the decrease of COD value. The highest decrease in BOD was $0.2 \mathrm{M}$ concentration of $0.2 \mathrm{M}$ sodium percarbonate from $0.213 \mathrm{mg} / \mathrm{L}$ to $0.0263 \mathrm{mg} / \mathrm{L}(\mathrm{BOD}$ removal $=$ $87.67 \%$ ), followed by $0.15 \mathrm{M}$ sodium percarbonate concentration $(\mathrm{BOD}$ removal $=83.78 \%$ ), then $0.1 \mathrm{M}$ 
sodium percarbonate concentration $(\mathrm{BOD}$ removal $=$ $78.26 \%$ ), and lowest at $0.05 \mathrm{M}$ sodium percarbonate concentration $(\mathrm{BOD}$ removal $=68.97 \%)$.

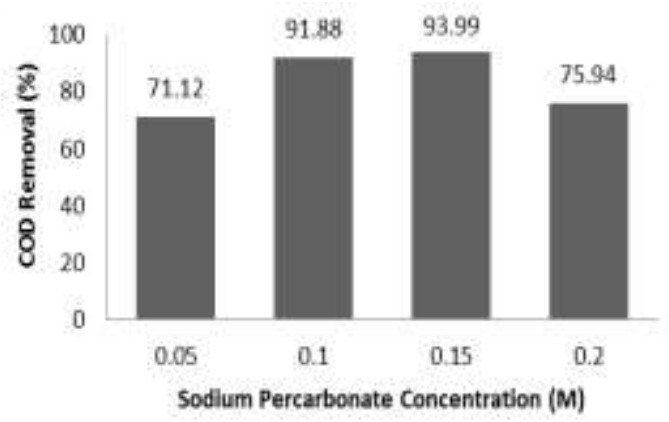

Fig 2. Reduction of COD levels with variation in sodium percarbonate concentration

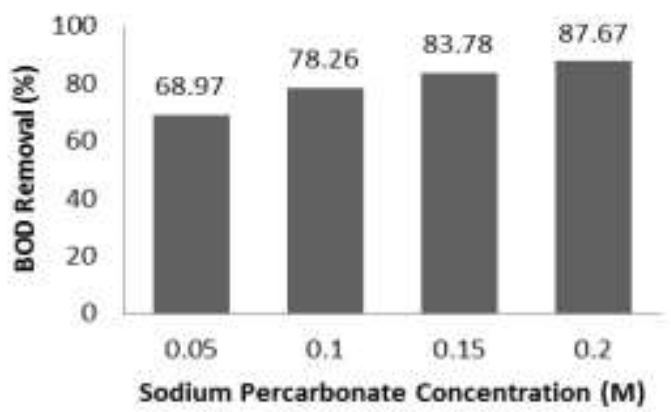

Fig 3. Reduction of BOD levels with variation in sodium percarbonate concentration

Sang, et al. (2006) states that the concentration of electrolyte solution has an effect on the resistance of electric double layer. Sang, et al. (2006) also says the coating is due to the salt chamber and the cathode chamber there is a limiting CEM membrane. This CEM membrane has a functional group of sulfonic origin of a negatively charged $\left(\mathrm{SO}_{3} \mathrm{H}\right)$ ionisation and forms a double electrical layer which creates an interface resistance between the (Ion Exchange Membrane) IEM membrane and the electrolyte solution (catholyte) ${ }^{[8]}$. The decrease in COD will be lower due to the lower concentration of the electrolyte solution so that the interface resistance between the CEM membrane and the electrolyte solution will be greater and will inhibit the transfer of protons from the salt chamber to the cathode chamber ${ }^{[8]}$.

In the results of research already contained in Fig. 2 and Fig. 3, the decrease in BOD content is in accordance with the theory put forward by Sang, et al. (2006), but on the COD decrease the best value was obtained on the operation of the MDC system with $0.15 \mathrm{M}$. sodium percarbonate concentration. This was due to the propelling factor, ie the dominant bacteria activity contained in the anolyte decreased because the $\mathrm{pH}$ value of anolyte was outside the optimum range for its growth [9]. Based on the literature results, the bacteria present in lake water are Escherichia coli bacteria, where the optimum $\mathrm{pH}$ value is $7-7.5^{[10]}$.

\subsection{Experiment with Variation of Bacteria Consortium Addition}

The MDC experiments with variations in the addition of this bacteria consortium used the best variation results from the variables of sodium percarbonate concentration in this study. The catholyte used was the optimum concentration of sodium percarbonate ie $0.15 \mathrm{M}$. Variations used for the addition of this bacteria consortium were $1 \mathrm{~mL}, 5 \mathrm{~mL}$, and $10 \mathrm{~mL}$. The purpose of the addition of this bakteria consortium is to know the effect of the presence of bacteria on the decreasing levels of COD and BOD of UI lake water in the MDC system that operates for 50 hours in a batch reactor.

The bacteria used are gram negative bacteria that comes from UI lake water. Gram colored staining results can be seen in Fig. 4 where the results obtained are gram negative bacteria. This is adjusted to research Mariana (2016) which proves that gram negative bacteria more positive effect on increasing electricity production in the MFC system. The positive effects of gram negative bacteria on COD and BOD decline in lake water are also due to gram-negative bacteria having thin peptidogligan walls where it makes it easy to transfer electrons to the anode $^{[11]}$.

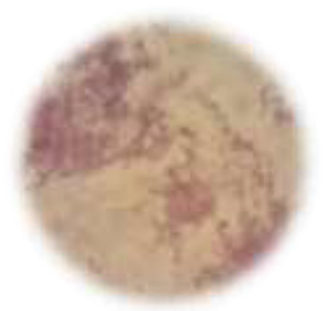

Fig 4. The result of gram bakteria staining. The color of bakteria is red, and the results obtained are gram negative bacteria

The decreasing performance of COD and BOD levels on the three MDC systems can be seen in Fig. $\mathbf{5}$ and Fig. 6. In Fig. 5 it can be seen that the highest decrease in COD levels was found in MDC system operation with the addition of $1 \mathrm{~mL}$ bakteria consortium, ie from 650 $\mathrm{mg} / \mathrm{L}$ to $64.75 \mathrm{mg} / \mathrm{L}$ with a decrease of COD by $90.04 \%$, followed by addition of bakteria consortium $5 \mathrm{~mL}$ (COD removal $=88.28 \%$ ), and the lowest increase in bakteria consortium $10 \mathrm{~mL}(\mathrm{COD}$ removal $=54.93 \%)$. The decrease in BOD can be seen in Fig. 6, where the graph of the decrease is equal to the decrease in COD value. The highest decrease of BOD was found in MDC system operation with addition of $1 \mathrm{~mL}$ bacteria consortium from $0.02 \mathrm{mg} / \mathrm{L}$ to $0.01 \mathrm{mg} / \mathrm{L}$ (BOD removal $=50.52 \%$ ), followed by addition of $5 \mathrm{~mL}$ bakteria consortium (BOD removal $=20.83 \%$ ), and the lowest increase in bacteria consortium $10 \mathrm{~mL}(\mathrm{BOD}$ removal $=8.33 \%)$. 


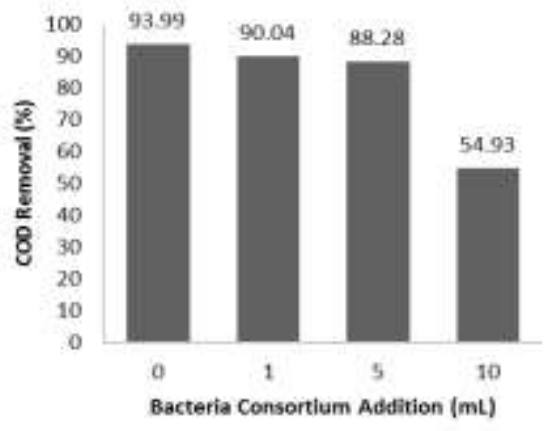

Fig. 5. Reduction COD levels with variations in the addition of bacteria consortium

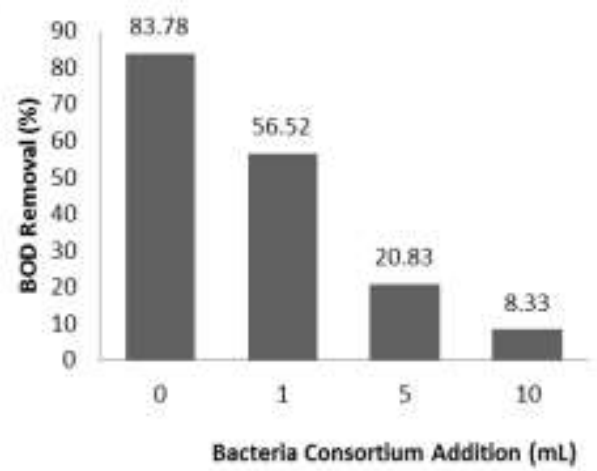

Fig. 6. Reduction COD levels with variations in the addition of bacteria consortium

The decrease of COD and BOD with the addition of the best bacteria consortium was found in addition of bacteria consortium of $1 \mathrm{~mL}$ of $90.04 \%$ for COD decrease and $56.53 \%$ for BOD decrease. This is because more and more bacteria are added to make the amount of existing nutrients is reduced because there is no addition of nutrients that cause a decrease in the speed of bakteria metabolism. In accordance with statement Lee, et al. (2010) that the energy produced is proportional to bakteria metabolism. According to Romayanto, et al. (2006), the amount of substrate (nutrients) that still result in decrease in the value of BOD due to the decrease in the amount of organic matter due to consumption by bacteria. The decline in the amount of bacteria that breaks down organic matter in waste into $\mathrm{CO}_{2}$ and ammonia due to the shortage of organic material derived from the substrate ${ }^{[12]}$. In addition, according to Mahida (1984) that the destruction of organic matter into $\mathrm{CO}_{2}$ and ammonia by bakteria activity occurs in the early stages will result in a decrease in the value of dissolved oxygen so that the BOD value is high. The continued existence of bakteria activity causes dissolved oxygen levels in waste water resulting in a decline in the decomposition process of organic matter as indicated by the decrease in $\mathrm{BOD}^{[13]}$. This can be seen in Fig. 6, where the addition of bakteria consortium as much as 10 $\mathrm{mL}$ decrease BOD it occurs only $8.33 \%$. According to Ishartanto (2009) the decrease of COD and BOD values on effluent is influenced by bakteria activity through transfer, conversion, and flocculation process so that its optimization depends on the continuity of bakteria contact time with organic material and the presence of oxygen in water.

\section{3 pH Changes}

\subsection{1 pH Changes in Anode Chamber}

The value of $\mathrm{pH}$ change in the anode chamber for the entire experiment can be seen in Fig.7.

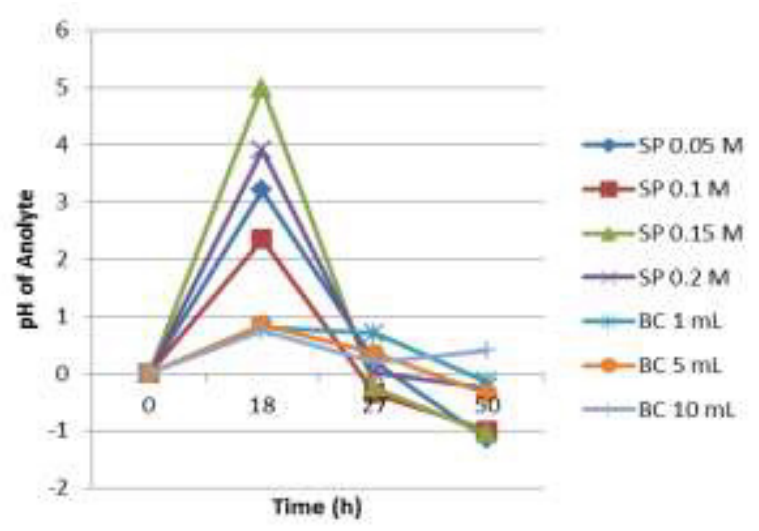

Fig. 7. pH changes in the anode chamber in each experiment

Based on the data shown in Fig. 7 the $\mathrm{pH}$ changes fluctuate, ie there is a $\mathrm{pH}$ rise and there is also a $\mathrm{pH}$ down time. According to Rout and Sharma (2010), an increase in $\mathrm{pH}$ value is caused by methane activity that will produce methane gas and reduce the content of hydrogen, carbon dioxide, and volatile fatty acids. While the $\mathrm{pH}$ decline in the anode chamber is due to an accumulation of proton events from cell metabolism ${ }^{[14]}$. The bacteria located in the anolyte will oxidize the substrate and will release $\mathrm{H}^{+}$ions and electrons ${ }^{[15]}$. The $\mathrm{pH}$ value outside the optimum range of bakteria growth can also inhibit the occurrence of bakteria activity ${ }^{[9]}$. In lake water, the dominant bacteria Escherichia coli have optimum $\mathrm{pH}$ growth of $7-7.5, \mathrm{pH}$ at least 4 , and $\mathrm{pH}$ maximum $9^{[10]}$. Based on that theory, the variation of 0.2 $\mathrm{M}$ sodium percarbonate concentration of COD decreasing value is less than optimal because the $\mathrm{pH}$ at the anode is less controlled by the presence of the sodium percarbonate, so the $\mathrm{pH}$ decrease from the 27 hour to the 50 hour is only 0.25 from 10.7 to 10.45 . While on the variation of $0.15 \mathrm{M}$ sodium percarbonate concentration became the most optimum variation due to the presence of sodium percarbonate capable of controlling the $\mathrm{pH}$ decrease from the 27 hours to the 50 hours with a significant of 1.05 from 11.65 to 10.45 so that bakteria activity can still run even with lower performance.

\subsection{2 pH Changes in Cathode Chamber}

The value of $\mathrm{pH}$ change in the cathode chamber for all experiments can be seen in Fig. 8. Based on the $\mathrm{pH}$ change $(\Delta \mathrm{pH})$ change data in Fig. 8 the cathode chamber is either $\mathrm{pH}$ or constant. In experiments with $0.05 \mathrm{M}$ sodium percarbonate concentration variation and addition of $1 \mathrm{~mL}$ bacteria consortium constant $\mathrm{pH}$ change or 0 (zero), indicated that sodium percarbonate has natural buffer capacity even without buffer $9^{[16]}$. This 
is because in the cathode chamber there is a hydrogen peroxide reduction reaction as an electron acceptor with catholyte sodium percarbonate, which according to Wiberg (2001), the hydrogen peroxide reduction mechanism into water is described in Eq. 1.

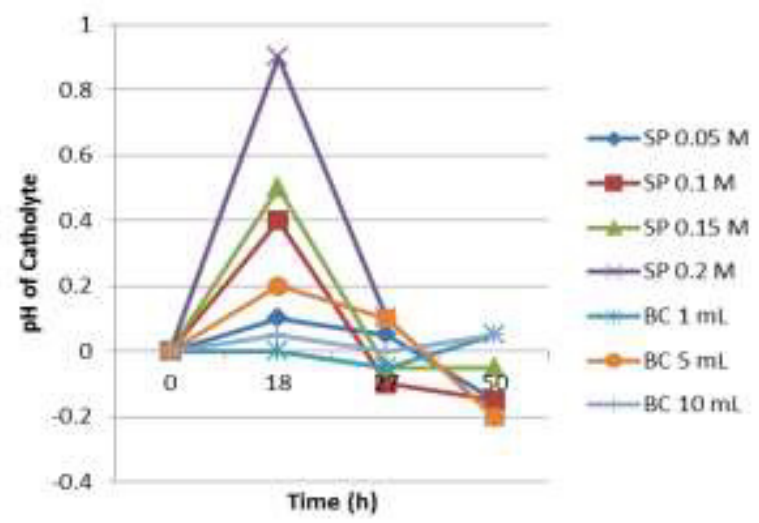

Fig 8. $\mathrm{pH}$ changes in the cathode chamber in each experiment

$\mathrm{HO}_{2}^{-}+\mathrm{H}_{2} \mathrm{O}+2 e^{-} \rightarrow 3 \mathrm{OH}^{-} / \mathrm{E}_{0}=+0,878 \mathrm{~V}($ base $\mathrm{pH})(1)$

The increase in $\mathrm{pH}$ of the cathode chamber is generally due to the formation of $\mathrm{NaOH}$. The higher the concentration of sodium percarbonate, the higher the buffer capacity is generated ${ }^{[17]}$. The statement is seen in $\Delta \mathrm{pH}$ from $0.05 \mathrm{M}$ concentrations to $0.2 \mathrm{M}$ which has increased.

\section{Conclusion}

The most maximum concentration of sodium percarbonate used for MDC system in UI lake water treatment is $0.15 \mathrm{M}$. Percentage of COD and BOD degradation levels at $0.15 \mathrm{M}$ sodium percarbonate concentration of $93.99 \%$ and $83.78 \%$. The addition of the most optimum bakteria consortium used for the MDC system in the UI lake water treatment is $1 \mathrm{~mL}$. Percentage of COD and BOD degradation of $90.04 \%$ and $56.52 \%$.

This research was supported by Publikasi Internasional Terindeks untuk Tugas Akhir Mahasiswa (PITTA), Direktorat Riset dan Pengabdian kepada Masyaratkat Universitas Indonesia (DRPM UI).

\section{References}

1. Tim Redaksi UI. Sampah di Danau UI, Tanggung Jawab Siapa?. [ONLINE] http://www.ui.ac.id/berita/sampah-di-danau-uitanggung-jawab-siapa.html (2014)

2. Tarsoen, Waryono. Danau UI Butuh Perhatian Intensif. http://www.suaramahasiswa.com (2012)

3. Larasati, Dinda. Danau UI Butuh Perhatian Intensif. [ONLINE] http://suaramahasiswa.com/\#/blog/BERITADanau-UI-ButuhPerhatian (2013)
4. Cao, X., X. Huang, P. Liang, K. Xiao, Y. Zhou, X. Zhang, B.E. Logan. A New Method for Water Desalination Using Microbial Desalination Cell. Environ. Sci. Technol. (43) 2009: 7148-7152. (2009)

5. Zhang, F., dan Z. He. Scaling up microbial desalination cell system with a post-aerobic process for simultaneous wastewater treatment and seawater desalination. Bioresource Technology 172 (2014): 429 - 432. (2015)

6. Kartiko, B. M. Desalinasi Menggunakan MDC (Microbial Desalination Cell) dengan Kultur Saccharomyces cerevisiae. Depok: Program Studi Teknologi Bioproses, Fakultas Teknik, Universitas Indonesia. (2013)

7. Putri, Syafira Andyah. Pengolahan Air Lindi Berbasis Microbial Desalination Cell Dengan Memanfaatkan Arang Hayati Sebaga Bioelektroda. Depok : Univeristas Indonesia (2017)

8. Sang, S., K. Huang, X. Li. The influence of H2SO4 electrolyte concentration on proton transfer resistance of membrane/solution interface. European Polymer Journal 42 (2006): 2894 - 2898. (2006)

9. Prakoso, Dio. Desalinasi air laut menggunakan Microbial Desalination Cell dengan substrat limbah cair industri tempe. Depok: FTUI (2014)

10. Faridz, ., Hafiluddin, Anshari. Analisis Junmlah Bakteri dan Keberadaan Erscherichia coli pada Pengolahan Ikan Teri Nasi di PT Kelola Mina Laut Unit Sumenep. Madura : Universitas Trunojoyo. (2007)

11. Mariana. Pengaruh Penambahan Selektif Mixed Culture Terhadap Produksi Energi Listrik Alternatif Berbasis Limbah Tempe Cair Pada Tubular Microbial Fuel Cell. Depok: Universitas Indonesia. (2016)

12. Romayanto, M. E. W., Wiryanto, Sajidan. Pengolahan limbah domestik dengan aerasi dan penambahan bakteri Pseudomonas putida. Surakarta : Uviversitas Sebelas Maret. (2006)

13. Mahida, U. N. Pencemaran Air dan Pemanfaatan Limbah Industri. CV. Rajawali. Jakarta. (1984)

14. Jacobson, K.S., Drew, D.M., \& He, Z. Use of a liter-scale microbial desalination cell as a platform to study bioelectrochemical desalination with salt solution or artificial seawater. Environ. Sci. Technol., 45, 46524657. (2011)

15. Saeed, H. M. et al. Microbial desalination cell technology: a review and case study. Desalination 359 (2015) 1-13. (2014)

16. Kamila, E. D., Utami, T. S., \& Arbianti, R. Natrium Perkarbonat sebagai Katolit Berpenyangga Alami dalam Sistem Microbial Desalination Cell. Journal UI Proceeding on Science and Technology, 1. (2016)

17. Forrestal, Z. Huang, Z.J. Ren. Percarbonate as a naturally buffering catholyte for microbial 
fuel cells. Bioresource Technology 172 (2014): 429-432. (2014) 